\title{
The influence of level of grain intake on protein digestion in the intestine of cattle
}

\author{
By T. S. NEUDOERFFER, P. A. LEADBEATER, \\ F. D. HORNEY AND H. S. BAYLEY \\ Departments of Nutrition and Clinical Studies, University of Guelph, \\ Guelph, Ontario, Canada
}

(Received 4 May 1970-Accepted 3 September 1970)

\begin{abstract}
1. Protein digestion in the gastro-intestinal tract of cattle receiving diets with either low or high content of maize was investigated. Digesta obtained from the duodenum and ileum were separated into three fractions; soluble, microbial and particulate, and the amino acid composition of the three fractions and that of the total digesta were determined. The proportion of particulate material digested in the intestine was less from the high-maize than from the lowmaize diet, but more of the particulate fraction entered the duodenum from the high-maize than from the low-maize diet, so the absolute amount of particulate fraction which was digested was greater for the high-maize diet.

2. More protein was digested in the rumen from the low-maize diet (high-roughage) than from the other diet. Total digestion of protein from the low-maize diet was also higher.

3. Although more protein from the high-maize than from the low-maize diet reached the duodenum, the protein from the low-maize diet was more digestible in the intestine, so the total amount of dietary protein digested in the intestine was the same for both rations.
\end{abstract}

It has been found that increasing the protein content of ruminant diets increases the loss of nitrogen which occurs between the mouth and the duodenum (Clarke, Ellinger \& Phillipson, 1966; Hogan \& Weston, 1967). This loss of nitrogen is due to microbial breakdown of protein in the rumen and absorption of ammonia in such quantities that there is an increase in the loss of urea in the urine (McDonald, r948). However, Nicholson \& Sutton (1969) have shown that there was a net gain of nitrogen between the mouth and the duodenum in sheep receiving a diet containing a large proportion of grain which supplied three times their maintenance requirement. Annison, Chalmers, Marshall \& Synge (1954) found that cereal grains are more resistant than other feeds to fermentation in the rumen and this could account for the increased flow of unmodified protein from the rumen to the duodenum of sheep receiving high-grain diets. The benefit to the animal of this increased amount of unfermented protein entering the intestine is doubtful, since Kay (1969) suggested plant protein is more resistant than microbial protein to intestinal hydrolysis. However, Ferguson, Hemsley \& Reis (I967) indicated that it was desirable to increase the amount of unfermented protein reaching the intestine, since Bergen, Purser \& Clive ( 1968 ) found that, during fermentation, the amino acid composition of the protein in the digesta was altered and the changes may have reduced the nutritional value of the protein. Lewis \& Emery (1962) and Phillipson (1964), for example, showed that there was a loss of sulphur amino acids by removal of SH groups. Thus, the extent to which dietary protein escapes fermentation in the rumen and the amount of this unfermented 
material which can be hydrolysed and absorbed in the intestine may have an important effect on the nutritional value of the protein for ruminants.

\section{EXPERIMENTAL}

Two Ayrshire heifers were used for these studies. Both animals had a rumen and an abomasal cannula in addition to an intestinal re-entrant cannula. The position of the re-entrant cannula in animal $\mathrm{S}$ was $0.70 \mathrm{~m}$ distal to the pylorus; the re-entrant cannula in animal $\mathrm{C}$ was $0.25 \mathrm{~m}$ proximal to the caecum. Maize, a poor-quality grass hay and a vitamin-mineral mix were the dietary ingredients. The low-maize

$\begin{array}{lcc}\text { Table I. Nitrogenous components of the air-dried foods } \\ & \text { Hay } & \text { Maize } \\ \text { Total nitrogen (g/roo) } & \text { I.33 } & \text { I.45 } \\ \text { Amino acids } & & \\ \text { (g/r6 g protein N): } & & \\ \text { Aspartic acid } & 8 \cdot 0 & 6 \cdot 3 \\ \text { Threonine } & 3 \cdot 7 & 3 \cdot 4 \\ \text { Serine } & 3 \cdot 8 & 4 \cdot 5 \\ \text { Glutamic acid } & 10 \cdot 8 & 18 \cdot 8 \\ \text { Proline } & 7 \cdot 5 & 9 \cdot 7 \\ \text { Glycine } & 9 \cdot 1 & 3 \cdot 9 \\ \text { Alanine } & 4 \cdot 9 & 7 \cdot 0 \\ \text { Cystine } & 1 \cdot 7 & 2 \cdot 0 \\ \text { Valine } & 4 \cdot 5 & 3 \cdot 1 \\ \text { Methionine } & 0 \cdot 7 & 2 \cdot 1 \\ \text { Isoleucine } & 8 \cdot 7 & 3 \cdot 2 \\ \text { Leucine } & 5 \cdot 4 & 10 \cdot 5 \\ \text { Tyrosine } & 6 \cdot 5 & 3 \cdot 0 \\ \text { Phenylalanine } & 4 \cdot 8 & 5 \cdot 1 \\ \text { Histidine } & 0 \cdot 7 & 4 \cdot 5 \\ \text { Lysine } & 3 \cdot 5 & 3 \cdot 9 \\ \text { Arginine } & 1 \cdot 3 & 4 \cdot 3\end{array}$

ration provided a daily intake of $2 \mathrm{~kg}$ maize and $4.5 \mathrm{~kg}$ hay; for the high-maize ration the amounts of maize and hay were 4 and $2 \mathrm{~kg}$ respectively. The animals received their daily allocation of food in two equal meals. The nitrogenous content of the hay and maize is shown in Table I. The proportions of hay and maize were selected such that both diets provided the same amounts of nitrogen with some allowance being made for a slightly higher amount of lignin nitrogen in the hay. The lowmaize diet supplied slightly more energy than was required for maintenance, whereas the high-maize diet supplied approximately twice this amount.

Digestion of dietary components was determined by means of total collection of the intestinal contents at the re-entrant cannula (Nicholson \& Sutton, 1969). The collection period was $8 \mathrm{~h}$. Lignin was estimated (Czerkawski, 1967) in the total digesta and the particulate fraction after freeze-drying. The dietary intake of lignin divided by its concentration in the dry matter was used to estimate flows. Initially, polyethylene glycol (PEG, average molecular weight 4000) was infused as a liquid flow marker; however, during preliminary experiments using $\left[{ }^{14} \mathrm{C}\right] \mathrm{PEG}$ and $\left[{ }^{3+} \mathrm{H}\right] \mathrm{PEG}$ (Neudoerffer, 
McLaughlin \& Horney, I970), it became apparent that the standard turbidimetric method (Smith, 1959) in our hands was unreliable. Since it was unpractical to use isotopically labelled PEG in full-scale flow experiments, the flow of supernatant and microbial matter was not adjusted. Protein content of the digesta was determined by macro-Kjeldahl analysis of freeze-dried material.

Samples of digesta were separated into three fractions: supernatant (soluble), microbial and particulate, by sucrose layer centrifugation (Gibbons \& Grandison, I966). The lower layer contained $40 \%(\mathrm{w} / \mathrm{v})$ sucrose, the upper layer $10 \%(\mathrm{w} / \mathrm{v})$. Centrifugation was for $5 \mathrm{~min}$ at $780 \mathrm{~g}$. The microbial matter which had been arrested at the sucrose layer interface after centrifugation, and the upper and lower sucrose phases, were aspirated from the sedimented particulate fraction and transferred to a second centrifuge flask. The microbial matter was then sedimented at $10000 \mathrm{~g}$ for $20 \mathrm{~min}$. Microscopic examination of both the particulate and microbial fraction showed little contamination of one with the other. Subsequent partitioning of either fraction in a fresh sucrose layer system yielded trace amounts ( $I-5 \%)$ of the other fraction. Six samples of duodenal digesta were separated into particulate and microbial fractions; the standard deviations of the means were 1.7 and $1 \cdot 3$ ( $\%$ of dry weight in samples) respectively. The same values for the six samples of ileal digesta were $3.4 \mathrm{I}$ and 3.0 respectively. Protein content of the fractions was estimated by micro-Kjeldahl analysis. Digesta fractions were hydrolysed with $6 \mathrm{~N}-\mathrm{HCl}$ for I $8 \mathrm{~h}$ at I I $5^{\circ}$ in sealed tubes which had been flushed with nitrogen before sealing. The amino acids were estimated with a Technicon (TSM) amino acid AutoAnalyzer. Four portions of one digesta sample were hydrolysed, and the results from the four chromatograms showed that the contents of methionine, isoleucine and serine ranged between $4 \cdot 4-4 \cdot 7,20 \cdot 1-20 \cdot 7$ and $29 \cdot 6-30 \cdot 5 \mu$ moles/g material respectively. Thus, although some destruction or incomplete liberation might have occurred (Kohler \& Palter, I967), the results were reproducible.

\section{RESULTS}

The amounts of digesta passing through the duodenal cannula were 50.3 and $5^{8.9} \mathrm{l} / \mathrm{d}$ for the low-maize and high-maize diets respectively, and the corresponding flows through the ileal cannula were 17.8 and $20.2 \mathrm{l} / \mathrm{d}$. The amount of protein digested

Table 2. Protein consumed, passing to the duodenum and passing the terminal part of the ileum $(\mathrm{g} / 24 \mathrm{~h})$ in heifers, calculated as (a) $N \times 6.25$ and $(b)$ the sum of the individual amino acids* (mean results for two runs)

\begin{tabular}{|c|c|c|c|c|c|c|c|c|c|}
\hline \multirow[b]{2}{*}{ Diet } & \multirow[b]{2}{*}{ Food } & \multicolumn{4}{|c|}{ Duodenum } & \multicolumn{4}{|c|}{ Ileum } \\
\hline & & Total & $\begin{array}{l}\text { Super- } \\
\text { natant }\end{array}$ & $\begin{array}{c}\text { Micro- } \\
\text { bial }\end{array}$ & $\begin{array}{c}\text { Partic- } \\
\text { ulate }\end{array}$ & Total & $\begin{array}{l}\text { Super- } \\
\text { natant }\end{array}$ & $\begin{array}{l}\text { Micro- } \\
\text { bial }\end{array}$ & $\begin{array}{l}\text { Partic- } \\
\text { ulate }\end{array}$ \\
\hline $\begin{array}{l}\text { Low- } \\
\text { maize: }(a) \\
\text { (b) }\end{array}$ & 553 & $\begin{array}{l}466 \\
398\end{array}$ & $\begin{array}{l}51 \\
48\end{array}$ & $\begin{array}{l}225 \\
206\end{array}$ & $\begin{array}{l}\text { I } 48 \\
\text { II } 5\end{array}$ & $\begin{array}{r}\text { II } 5 \\
80\end{array}$ & $\begin{array}{l}27 \\
14\end{array}$ & $\begin{array}{l}32 \\
20\end{array}$ & $\begin{array}{l}57 \\
42\end{array}$ \\
\hline $\begin{array}{l}\text { High- } \\
\text { maize: }(a) \\
(b)\end{array}$ & 534 & $\begin{array}{l}484 \\
464\end{array}$ & $\begin{array}{l}63 \\
60\end{array}$ & $\begin{array}{l}\mathbf{1 9 6} \\
186\end{array}$ & $\begin{array}{l}219 \\
190\end{array}$ & $\begin{array}{l}149 \\
120\end{array}$ & $\begin{array}{l}23 \\
13\end{array}$ & $\begin{array}{l}30 \\
20\end{array}$ & $\begin{array}{l}96 \\
78\end{array}$ \\
\hline
\end{tabular}


in various parts of the gut is shown in Table 2. The amount has been calculated in two ways: either as crude protein $(\% \mathrm{~N} \times 6 \cdot 25)$ or as the sum of the individual amino acids determined on hydrolysates of the samples. The flows of total digesta and of the particulate fraction were corrected for variation in rates of flow, but the correction could

Table 3. Amino acids consumed, passing to the duodenum and passing the terminal part of the ileum $(g / 24 h)$ in heifers given a low-maize diet $(L M)$ or a high-maize diet (HM)

\begin{tabular}{|c|c|c|c|c|c|c|c|c|c|c|}
\hline \multirow[b]{2}{*}{ Amino acid } & \multirow[b]{2}{*}{ Diet } & \multirow[b]{2}{*}{ Food } & \multicolumn{4}{|c|}{ Duodenum } & \multicolumn{4}{|c|}{ Ileum } \\
\hline & & & Total & $\begin{array}{l}\text { Super- } \\
\text { natant }\end{array}$ & $\begin{array}{l}\text { Micro- } \\
\text { bial }\end{array}$ & $\begin{array}{l}\text { Parti- } \\
\text { culate }\end{array}$ & Total & $\begin{array}{l}\text { Super- } \\
\text { natant }\end{array}$ & $\begin{array}{l}\text { Micro- } \\
\text { bial }\end{array}$ & $\begin{array}{l}\text { Parti- } \\
\text { culate }\end{array}$ \\
\hline $\begin{array}{l}\text { Aspartic } \\
\text { acid }\end{array}$ & $\begin{array}{l}\text { LM } \\
\text { HM }\end{array}$ & $\begin{array}{l}38 \cdot 2 \\
36 \cdot 5\end{array}$ & $\begin{array}{l}37 \cdot 1 \\
38 \cdot 4\end{array}$ & $\begin{array}{l}4 \cdot 4 \\
6 \cdot 2\end{array}$ & $\begin{array}{l}\text { I } 9 \cdot 9 \\
\text { I } 8 \cdot 0\end{array}$ & $\begin{array}{l}\text { I0.8 } \\
\text { I } 6.3\end{array}$ & $\begin{array}{r}6.9 \\
10 \cdot 1\end{array}$ & $\begin{array}{l}\mathrm{r} \cdot 3 \\
0.9\end{array}$ & $\begin{array}{l}\mathrm{I} \cdot 6 \\
\mathrm{I} \cdot 6\end{array}$ & $\begin{array}{l}3 \cdot 7 \\
6 \cdot 4\end{array}$ \\
\hline Threonine & $\begin{array}{l}\text { LM } \\
\text { HM }\end{array}$ & $\begin{array}{l}18.6 \\
18.8\end{array}$ & $\begin{array}{l}19 \cdot 7 \\
22 \cdot 0\end{array}$ & $\begin{array}{l}2 \cdot 2 \\
2 \cdot 9\end{array}$ & $\begin{array}{r}10 \cdot 4 \\
9 \cdot 1\end{array}$ & $\begin{array}{l}5 \cdot 5 \\
8 \cdot 2\end{array}$ & $\begin{array}{l}3.8 \\
5.7\end{array}$ & $\begin{array}{l}0.8 \\
0.6\end{array}$ & $\begin{array}{l}1.0 \\
0.9\end{array}$ & $\begin{array}{l}2 \cdot 0 \\
3 \cdot 8\end{array}$ \\
\hline Serine & $\begin{array}{l}\text { LM } \\
\text { HM }\end{array}$ & $\begin{array}{l}21 \cdot 0 \\
23 \cdot 1\end{array}$ & $\begin{array}{l}19 \cdot 8 \\
23 \cdot 1\end{array}$ & $\begin{array}{l}2 \cdot 1 \\
3 \cdot 1\end{array}$ & $\begin{array}{r}10 \cdot 3 \\
8.8\end{array}$ & $\begin{array}{l}5 \cdot 4 \\
9 \cdot 5\end{array}$ & $\begin{array}{l}3 \cdot 4 \\
5 \cdot 2\end{array}$ & $\begin{array}{l}0.6 \\
0.5\end{array}$ & $\begin{array}{l}0.9 \\
0.8\end{array}$ & $\begin{array}{l}1 \cdot 9 \\
3 \cdot 6\end{array}$ \\
\hline $\begin{array}{l}\text { Glutamic } \\
\text { acid }\end{array}$ & $\begin{array}{l}\mathrm{LM} \\
\mathrm{HM}\end{array}$ & $\begin{array}{l}75 \cdot 1 \\
87 \cdot 5\end{array}$ & $\begin{array}{l}50 \cdot 1 \\
58 \cdot 3\end{array}$ & $\begin{array}{l}4 \cdot 6 \\
7 \cdot 5\end{array}$ & $\begin{array}{l}26 \cdot 9 \\
24 \cdot 2\end{array}$ & $\begin{array}{l}16 \cdot 4 \\
25 \cdot 8\end{array}$ & $\begin{array}{l}10.1 \\
15.3\end{array}$ & $\begin{array}{l}\mathrm{I} \cdot 4 \\
\mathrm{I} \cdot 2\end{array}$ & $\begin{array}{l}2 \cdot 5 \\
2 \cdot 4\end{array}$ & $\begin{array}{r}5.7 \\
10.6\end{array}$ \\
\hline Proline & $\begin{array}{l}\text { LM } \\
\text { HM }\end{array}$ & $\begin{array}{l}43 \cdot 0 \\
48 \cdot 4\end{array}$ & $\begin{array}{l}21 \cdot 4 \\
28 \cdot 3\end{array}$ & $\begin{array}{l}2 \cdot I \\
3 \cdot I\end{array}$ & $\begin{array}{l}10.5 \\
10 \cdot 1\end{array}$ & $\begin{array}{r}7 \cdot 3 \\
\times 2 \cdot 9\end{array}$ & $\begin{array}{l}6 \cdot 1 \\
8 \cdot 9\end{array}$ & $\begin{array}{l}0.5 \\
0.5\end{array}$ & $\begin{array}{l}2.5 \\
\mathrm{r} \cdot 8\end{array}$ & $\begin{array}{l}2 \cdot 7 \\
6 \cdot 0\end{array}$ \\
\hline Glycine & $\begin{array}{l}\text { LM } \\
\text { HM }\end{array}$ & $\begin{array}{l}2 I \cdot 6 \\
2 I \cdot 6\end{array}$ & $\begin{array}{l}27 \cdot 9 \\
30^{\circ} \cdot 1\end{array}$ & $\begin{array}{l}6 \cdot 3 \\
6 \cdot 1\end{array}$ & $\begin{array}{l}12 \cdot 6 \\
10 \cdot 8\end{array}$ & $\begin{array}{r}7 \cdot 2 \\
11 \cdot 0\end{array}$ & $\begin{array}{l}4 \cdot 7 \\
7 \cdot 8\end{array}$ & $\begin{array}{l}0.7 \\
0.4\end{array}$ & $\begin{array}{l}I \cdot I \\
I \cdot I\end{array}$ & $\begin{array}{l}2 \cdot 6 \\
4 \cdot 8\end{array}$ \\
\hline Alanine & $\begin{array}{l}\text { LM } \\
\text { HM }\end{array}$ & $\begin{array}{l}29 \cdot 2 \\
33 \cdot 9\end{array}$ & $\begin{array}{l}21 \cdot 9 \\
28 \cdot 6\end{array}$ & $\begin{array}{l}4 \cdot 4 \\
3 \cdot 0\end{array}$ & $\begin{array}{l}10.5 \\
11.9\end{array}$ & $\begin{array}{r}3.9 \\
13.0\end{array}$ & $\begin{array}{l}3 \cdot 9 \\
4^{\cdot} \cdot 1\end{array}$ & $\begin{array}{l}0.5 \\
0.4\end{array}$ & $\begin{array}{l}I \cdot 0 \\
I \cdot I\end{array}$ & $\begin{array}{l}2 \cdot 1 \\
2 \cdot 6\end{array}$ \\
\hline Cystine & $\begin{array}{l}\text { LM } \\
\text { HM }\end{array}$ & $\begin{array}{r}9.6 \\
\text { 10.3 }\end{array}$ & $\begin{array}{l}7 \cdot 6 \\
8 \cdot 4\end{array}$ & $\begin{array}{l}I \cdot 4 \\
I \cdot 0\end{array}$ & $\begin{array}{l}4 \cdot 8 \\
\mathrm{I} \cdot 2\end{array}$ & $\begin{array}{l}I \cdot 8 \\
2 \cdot 5\end{array}$ & $\begin{array}{l}2 \cdot 7 \\
3 \cdot 8\end{array}$ & $\begin{array}{l}0.5 \\
0.3\end{array}$ & $\begin{array}{l}0 \cdot 6 \\
\mathrm{x} \cdot 3\end{array}$ & $\begin{array}{l}I \cdot 3 \\
2 \cdot 3\end{array}$ \\
\hline Valine & $\begin{array}{l}\text { LM } \\
\text { HM }\end{array}$ & $\begin{array}{l}20.7 \\
19.0\end{array}$ & $\begin{array}{l}21 \cdot 7 \\
25 \cdot I\end{array}$ & $\begin{array}{l}2 \cdot 2 \\
3 \cdot I\end{array}$ & $\begin{array}{l}11 \cdot 9 \\
10 \cdot 7\end{array}$ & $\begin{array}{r}6 \cdot 6 \\
10 \cdot 3\end{array}$ & $\begin{array}{l}4 \cdot 6 \\
7 \cdot 3\end{array}$ & $\begin{array}{l}0.7 \\
0.5\end{array}$ & $\begin{array}{l}I \cdot I \\
I \cdot 2\end{array}$ & $\begin{array}{l}2 \cdot 4 \\
4 \cdot 7\end{array}$ \\
\hline Methionine & $\begin{array}{l}\text { LM } \\
\text { HM }\end{array}$ & $\begin{array}{l}6 \cdot 3 \\
9 \cdot 1\end{array}$ & $\begin{array}{r}8 \cdot 3 \\
\times 3 \cdot 2\end{array}$ & $\begin{array}{l}0.9 \\
2.0\end{array}$ & $\begin{array}{l}3 \cdot 9 \\
3 \cdot I\end{array}$ & $\begin{array}{l}I \cdot 9 \\
4 \cdot 4\end{array}$ & $\begin{array}{l}x \cdot 5 \\
2 \cdot 6\end{array}$ & $\begin{array}{l}0.3 \\
0.2\end{array}$ & $\begin{array}{l}0.5 \\
0.6\end{array}$ & $\begin{array}{l}0.7 \\
I .6\end{array}$ \\
\hline Isoleucine & $\begin{array}{l}\text { LM } \\
\text { HM }\end{array}$ & $\begin{array}{l}12 \cdot 3 \\
15 \cdot 2\end{array}$ & $\begin{array}{l}22 \cdot 3 \\
21 \cdot 0\end{array}$ & $\begin{array}{l}1 \cdot 7 \\
2 \cdot 4\end{array}$ & $\begin{array}{r}11 \cdot 0 \\
9 \cdot 2\end{array}$ & $\begin{array}{l}6 \cdot I \\
9 \cdot 3\end{array}$ & $\begin{array}{l}3 \cdot 9 \\
4 \cdot 8\end{array}$ & $\begin{array}{l}0.5 \\
0.3\end{array}$ & $\begin{array}{l}0.8 \\
0.8\end{array}$ & $\begin{array}{l}1.6 \\
3.5\end{array}$ \\
\hline Leucine & $\begin{array}{l}\text { LM } \\
\text { HM }\end{array}$ & $\begin{array}{l}37 \cdot 2 \\
47 \cdot 7\end{array}$ & $\begin{array}{l}33 \cdot I \\
42 \cdot I\end{array}$ & $\begin{array}{l}3 \cdot 2 \\
5 \cdot 1\end{array}$ & $\begin{array}{l}16 \cdot 3 \\
15.6\end{array}$ & $\begin{array}{l}\text { II } \cdot 2 \\
19 \cdot 1\end{array}$ & $\begin{array}{r}5 \cdot 3 \\
10 \cdot 4\end{array}$ & $\begin{array}{l}0.8 \\
0.5\end{array}$ & $\begin{array}{l}I \cdot 4 \\
I \cdot 3\end{array}$ & $\begin{array}{l}3 \cdot 1 \\
7 \cdot 3\end{array}$ \\
\hline Tyrosine & $\begin{array}{l}\text { LM } \\
\text { HM }\end{array}$ & $\begin{array}{l}14.2 \\
15.4\end{array}$ & $\begin{array}{l}15 \cdot 3 \\
17 \cdot 3\end{array}$ & $\begin{array}{l}2 \cdot 6 \\
3 \cdot 0\end{array}$ & $\begin{array}{l}9 \cdot 2 \\
7 \cdot 6\end{array}$ & $\begin{array}{l}3.9 \\
6.7\end{array}$ & $\begin{array}{l}2 \cdot 4 \\
4 \cdot 0\end{array}$ & $\begin{array}{l}0.6 \\
0.3\end{array}$ & $\begin{array}{l}0.8 \\
0.7\end{array}$ & $\begin{array}{l}I \cdot I \\
2 \cdot 9\end{array}$ \\
\hline Phenylalanine & $\begin{array}{l}\text { LM } \\
\text { HM }\end{array}$ & $\begin{array}{l}24 \cdot 2 \\
26 \cdot 7\end{array}$ & $\begin{array}{l}26 \cdot 6 \\
28 \cdot 4\end{array}$ & $\begin{array}{l}2 \cdot 1 \\
3 \cdot 0\end{array}$ & $\begin{array}{l}13.3 \\
10.4\end{array}$ & $\begin{array}{r}7 \cdot 4 \\
11 \cdot 0\end{array}$ & $\begin{array}{r}6.1 \\
10.6\end{array}$ & $\begin{array}{l}I \cdot 4 \\
I \cdot 3\end{array}$ & $\begin{array}{l}I \cdot 5 \\
I \cdot 3\end{array}$ & $\begin{array}{l}3 \cdot 1 \\
6 \cdot 7\end{array}$ \\
\hline Histidine & $\begin{array}{l}\text { LM } \\
\text { HM }\end{array}$ & $\begin{array}{l}10.7 \\
17.7\end{array}$ & $\begin{array}{l}14.5 \\
20.0\end{array}$ & $\begin{array}{l}2 \cdot 0 \\
I \cdot 9\end{array}$ & $\begin{array}{l}7 \cdot 9 \\
8 \cdot 1\end{array}$ & $\begin{array}{l}5 \cdot 2 \\
9 \cdot 1\end{array}$ & $\begin{array}{l}3.9 \\
3.5\end{array}$ & $\begin{array}{l}I \cdot 3 \\
I \cdot 1\end{array}$ & $\begin{array}{l}0.8 \\
0.7\end{array}$ & $\begin{array}{l}I \cdot 6 \\
I \cdot 8\end{array}$ \\
\hline Lysine & $\begin{array}{l}\text { LM } \\
\text { HM }\end{array}$ & $\begin{array}{l}18 \cdot 0 \\
18 \cdot 5\end{array}$ & $\begin{array}{l}27 \cdot 9 \\
32 \cdot 1\end{array}$ & $\begin{array}{l}2 \cdot 9 \\
4 \cdot 3\end{array}$ & $\begin{array}{l}\text { I } 3.9 \\
\text { I } 5.3\end{array}$ & $\begin{array}{r}9.0 \\
12.5\end{array}$ & $\begin{array}{l}4.4 \\
9.4\end{array}$ & $\begin{array}{l}0.8 \\
0.8\end{array}$ & $\begin{array}{l}I \cdot 2 \\
1 \cdot 2\end{array}$ & $\begin{array}{l}2 \cdot 3 \\
5 \cdot 9\end{array}$ \\
\hline Arginine & $\begin{array}{l}\text { LM } \\
\text { HM }\end{array}$ & $\begin{array}{l}12 \cdot I \\
18 \cdot 0\end{array}$ & $\begin{array}{l}22 \cdot 9 \\
27 \cdot 1\end{array}$ & $\begin{array}{l}2 \cdot 6 \\
2 \cdot 4\end{array}$ & $\begin{array}{l}\text { ro. } 8 \\
\text { I } 1.6\end{array}$ & $\begin{array}{l}6 \cdot 1 \\
8 \cdot 4\end{array}$ & $\begin{array}{l}6 \cdot 3 \\
7 \cdot 1\end{array}$ & $\begin{array}{l}\times \cdot 5 \\
2 \cdot 7\end{array}$ & $\begin{array}{l}I \cdot I \\
I \cdot 2\end{array}$ & $\begin{array}{l}3 \cdot 3 \\
2 \cdot 8\end{array}$ \\
\hline
\end{tabular}

not be applied to those of the microbial and supernatant fractions. Thus the sums of the protein in each fraction did not equal the amount determined on the total digesta.

Comparisons of the amounts of crude protein in the food with that passing through the duodenal cannula showed that a net loss of nitrogen occurred in the rumen. The net nitrogen loss was less for the high-maize diet, and comparisons of the amounts of 
crude protein and total amino acids reaching the duodenum show that less of the crude protein was made up of amino acids with the lower intake of maize. These comparisons indicate that the protein in the high-maize ration was more resistant to rumen microbial fermentation than that in the low-maize ration.

Examination of the protein passing through the duodenum showed that with the low-maize diet the major part of the protein was microbial, whereas with the highmaize diet a greater proportion remained in the particulate fraction. The amount of soluble protein was greater with the higher maize intake, which may indicate more extensive proteolysis in the abomasum or greater pancreatic secretion.

The amounts of material passing through the ileal cannula indicated that more crude protein escaped absorption with the high than with the low maize intake (I49 compared with Ir $5 \mathrm{~g} / \mathrm{d}$ ). The total amounts of amino acids from the two diets showed a similar difference. Fractionation of the protein passing through the ileum indicated that a greater amount of protein from the high-maize than from the low-maize ration was in the particulate fraction; the amounts of soluble and microbial protein were similar for the two diets.

The amino acid composition of the diets, the total digesta and the digesta fractions are shown in Table 3. Again, because only the flow of total digesta and of the particulate matter could be adjusted for variations of flow-rates, the sums of amino acids of each fraction did not equal the amounts determined in the total digesta.

The intakes of aspartic acid were similar for both diets, $38 \cdot 2$ and $36 \cdot 5 \mathrm{~g} / \mathrm{d}$, respectively, but the intakes of methionine, isoleucine, leucine, histidine and arginine were all increased by raising the intake of maize. Comparisons of the amounts of amino acid in the diet with the amounts entering the duodenum showed marked increases in the amounts of glycine, isoleucine, lysine and arginine and decreases in the amounts of glutamic acid, alanine and leucine. In the duodenal digesta the amounts of amino acids in the supernatant and in the microbial fractions were similar for the two diets, but increasing the maize intake increased the amount of each amino acid in the particulate fraction, e.g. 16.3 compared with $10.8 \mathrm{~g}$ aspartic acid. Comparisons of the amounts of amino acids entering the duodenum with those leaving the ileum showed that there was a greater loss of amino acids for the high-maize than for the low-maize diet (i.e. $10 . \mathrm{g}$ compared with $6.9 \mathrm{~g}$ aspartic acid), and this greater loss of amino acids was in the particulate fraction, e.g. 6.4 compared with $3.7 \mathrm{~g}$ aspartic acid.

\section{DISCUSSION}

Table 4 is a summary of the results for digestion and absorption of nitrogen from the gastro-intestinal tract with the two diets. With both diets, a net loss of nitrogen was observed in the rumen; however, the loss was less with the high-maize diet. This result differs from that of Nicholson \& Sutton (1969), who found a net gain in nitrogen in the rumen of sheep that received rations with a high grain content. Quantitative comparison of these results with those obtained by others may, however, not be valid because of differences in the diets used. The three diets used by Nicholson \& Sutton (1969), for instance, did not supply the same protein intake as that given in our experiment. 
The amount of nitrogen (expressed as a percentage of intake) which disappeared in the stomach and small intestine was less with the high-maize than with the lowmaize diet, which agrees with the observation of Nicholson \& Sutton (1969). Furthermore, increasing the intake of maize appeared to reduce the disappearance of protein in the small intestine $(69 \cdot 2$ compared with $75 \cdot 4 \%)$. However, there did not seem to

Table 4. Protein digestion in the gastro-intestinal tract of heifers, calculated as (a) $N \times 6.25$ and (b) the sum of the individual amino acids

\begin{tabular}{|c|c|c|c|c|}
\hline \multirow[b]{2}{*}{ Diet } & \multicolumn{3}{|c|}{$\%$ loss of dietary protein from: } & \multirow{2}{*}{$\begin{array}{l}\% \text { of dietary } \\
\text { protein } \\
\text { digested } \\
\text { in the } \\
\text { intestine }\end{array}$} \\
\hline & $\begin{array}{l}\text { Mouth to } \\
\text { duodenum }\end{array}$ & $\begin{array}{l}\text { Mouth to } \\
\text { ileum }\end{array}$ & $\begin{array}{l}\text { Duodenum } \\
\text { to ileum }\end{array}$ & \\
\hline \multicolumn{5}{|l|}{ Low- } \\
\hline maize: $(a)$ & 17.7 & 79 & $75^{\circ}$ & $63 \cdot 5$ \\
\hline & $28 \cdot I$ & $85 \cdot 6$ & 80.0 & 57.5 \\
\hline \multicolumn{5}{|l|}{ High- } \\
\hline maize: $(a)$ & $9 \cdot 4$ & $72 \cdot 2$ & $69 \cdot 2$ & $62 \cdot 8$ \\
\hline (b) & I $3 \cdot I$ & $77 \cdot 5$ & $74 \cdot 2$ & $62 \cdot 7$ \\
\hline
\end{tabular}

Table 5. Extent of digestion of the protein of the particulate fraction in the intestine of heifers, calculated as (a) $N \times 6.25$ and (b) the sum of the individual amino acids

\begin{tabular}{|c|c|c|}
\hline Diet & $\begin{array}{l}\% \text { of dietary } \\
\text { protein digested } \\
\text { in the intestine } \\
\text { as particulate } \\
\text { fraction }\end{array}$ & $\begin{array}{l}\% \text { of particulate } \\
\text { fraction digested } \\
\text { in the intestine }\end{array}$ \\
\hline $\begin{array}{l}\text { Low- } \\
\text { maize: }(a) \\
\qquad(b)\end{array}$ & $\begin{array}{l}16.5 \\
13.2\end{array}$ & $\begin{array}{l}61 \cdot 5 \\
63.8\end{array}$ \\
\hline $\begin{array}{l}\text { High- } \\
\text { maize: }(a) \\
\qquad(b)\end{array}$ & $\begin{array}{l}23 \cdot I \\
20.8\end{array}$ & $\begin{array}{l}55 \cdot 6 \\
58 \cdot 5\end{array}$ \\
\hline
\end{tabular}

be a difference between the two rations in the amount of protein expressed as a percentage of intake which was digested in the intestine $(63.5$ compared with $62.8 \%)$. Therefore, although more of the dietary protein from the low-maize ration was digested, the increase did not appear to provide the animals with a larger supply of amino acids.

The particulate fraction was assumed to be food which had escaped fermentation in the rumen, and the extent of digestion of this material in the small intestine is summarized in Table 5. Increasing the intake of maize increased the amount of unfermented material passing both the duodenal and ileal cannulas. The greater supply of unfermented material from the high-maize ration resulted in more of the particulate fraction of the food being digested in the intestine (23.1 compared with I6.5\%). However, the total digestion of the unfermented material appeared to be reduced by increasing the maize intake $(55.6$ compared with $61.5 \%$ of protein entering the intestine). These observations support previous suggestions that plant protein is not readily hydrolysed and absorbed from the intestine (Kay, 1969), and they show 
also that high-grain diets may result in a substantial absorption of unmodified dietary protein by the animal.

Consideration of the amino acid digestion in the intestine is complicated by the mixing of the exogenous protein with endogenous secretions (Nasset \& Ju, I96I). However, Snook \& Meyer ( $\left.\mathrm{r}^{6} 64\right)$ indicated that, in the rat, $88 \%$ of the endogenous protein disappeared from the lumen of the distal region of the small intestine. If similar resorption of endogenous nitrogen occurs in cattle, the comparisons of the amount of amino acid passing the distal ileum give an indication of the relative availability of the amino acids from the two rations.

Table 6. Net gain $(g / 24 h)$ of some amino acids to the heifers on the low-maize $(L M)$ and on the high-maize (HM) diet

\begin{tabular}{|c|c|c|c|c|c|c|c|c|}
\hline & \multicolumn{2}{|c|}{ Methionine } & \multicolumn{2}{|c|}{ Histidine } & \multicolumn{2}{|c|}{ Lysine } & \multicolumn{2}{|c|}{ Phenylalanine } \\
\hline & LM & $\mathrm{HM}$ & LM & HM & $\mathrm{LM}$ & $\mathrm{HM}$ & $\mathrm{LM}$ & HM \\
\hline & $6 \cdot 3$ & $9 \cdot I$ & $10 \cdot 7$ & $17 \cdot 7$ & $18 \cdot 0$ & $18 \cdot 5$ & $24 \cdot 2$ & $26 \cdot 7$ \\
\hline $\begin{array}{l}\text { eum } \\
\text { et gain }\end{array}$ & $\begin{array}{l}\mathrm{I} \cdot 5 \\
4 \cdot 8\end{array}$ & $\begin{array}{l}2 \cdot 6 \\
6 \cdot 5\end{array}$ & 3.9 & 3.5 & 4.4 & $9 \cdot 4$ & $6 \cdot I$ & $10 \cdot 6$ \\
\hline et gain & & 6.5 & 6.8 & 14.2 & $13 \cdot 6$ & $9 \cdot I$ & I 8.1 & $I 6 \cdot I$ \\
\hline
\end{tabular}

Table 7. Flows of some amino acids through the ileum in the particulate fraction, expressed as $\mathrm{g} / 24 \mathrm{~h}$ and as a percentage of the flow through the duodenum in the particulate fraction, in heifers given a low-maize (LM) or a high-maize (HM) diet

\begin{tabular}{|c|c|c|c|c|c|c|c|c|}
\hline & \multicolumn{2}{|c|}{ Methionine } & \multicolumn{2}{|c|}{ Histidine } & \multicolumn{2}{|c|}{ Lysine } & \multicolumn{2}{|c|}{ Phenylalanine } \\
\hline & LM & $\mathrm{HM}$ & LM & HM & LM & HM & LM & HM \\
\hline $\begin{array}{l}\text { Ileum flow } \\
(\mathrm{g} / 24 \mathrm{~h})\end{array}$ & 0.7 & $I \cdot 6$ & $x \cdot 6$ & I.8 & $2 \cdot 3$ & $5 \cdot 9$ & $3 \cdot x$ & 6.7 \\
\hline $\begin{array}{l}\text { Ileum flow } \\
\text { (as \% of } \\
\text { duodenum } \\
\text { flow) }\end{array}$ & 37 & 36 & $3 \mathbf{I}$ & 20 & 25 & 47 & 42 & 60 \\
\hline
\end{tabular}

The increase in the level of maize increases the intake of most amino acids from the intestine and a net gain to the animal of methionine and histidine, for instance, was observed (Table 6). In contrast, the greater intake of lysine and phenylalanine provided by the high-maize diet resulted in reductions in the net gains of these amino acids to the animal.

The greater net gain of methionine and histidine as a result of increasing the intake of maize may be due to a constant utilization of the amino acids from the particulate fraction of the digesta entering the duodenum from the two diets (Table 7), whereas the decrease in net gain of lysine and phenylalanine appears to result from a lower digestibility of these two amino acids in the particulate fraction entering the duodenum from the high-maize diets.

The authors thank Mr R. Emslie for valued assistance with the animal experiments and Mrs R. Dunn for laboratory analyses. The financial support of the Ontario Department of Agriculture and Food is gratefully acknowledged. 


\section{REFERENCES}

Annison, E. F., Chalmers, M. I., Marshall, S. B. M. \& Synge, R. L. M. (1954). F. agric. Sci., Camb. 44, 270.

Bergen, W. G., Purser, D. B. \& Clive, J. H. (r968). F. Anim. Sci. 27, r 497.

Clarke, E. M. W., Ellinger, G. M. \& Phillipson, A. T. (1966). Proc. R. Soc. B 166, 63.

Czerkawski, J. W. (r967). Br. F. Nutr. 21, 325.

Ferguson, K. A., Hemsley, J. A. \& Reis, P. J. (1967). Aust. F. Sci. 3o, 215.

Gibbons, L. N. \& Grandison, G. S. (1966). Nematologica 12, 642.

Hogan, J. P. \& Weston, R. H. (1967). Aust. F. agric. Res. 18, 973.

Kay, R. N. B. (1969). Proc. Nutr. Soc. 28, 140.

Kohler, G. O. \& Palter, R. (1967). Cereal Chem. 44, 512.

Lewis, T. R. \& Emery, R. S. (1962). F. Dairy Sci. 45, 765 .

McDonald, I. W. (1948). Biochem. F. 42, 584.

Nasset, E. S. \& Ju, J. S. (196r). F. Nutr. 74, 46 r.

Neudoerffer, R. S., McLaughlin, D. R. \& Horney, F. D. (1970). F. Anim. Sci. 31, 1042.

Nicholson, J. W. G. \& Sutton, J. D. (I 969). Br. $¥$. Nutr. 23, 585 .

Phillipson, A. T. (1964). In Mammalian Protein Metabolism Vol. x, p. 7I [H. N. Munro and J. B. Allison, editors]. New York: Academic Press.

Smith, R. H. (1959). F. agric. Sci., Camb. 52, 72.

Snook, J. T. \& Meyer, J. H. (x964). In The Role of the Gastrointestinal Tract in Protein Metabolism p. 96. [H. N. Munro, editor]. Oxford: Blackwell. 